\title{
SCREENING OF RHAMNOLIPID PRODUCED BY MARINE BACTERIUM FOR HEAVY METAL REMOVAL IN MANGROVE SOIL
}

\author{
RAVEENA, K. ${ }^{\mathrm{A}}$, ARULARASU, M. ${ }^{\mathrm{B}}$, GANESAN, S.S. K. ${ }^{\mathrm{C}}$, AMELIA, T.S.M. ${ }^{\mathrm{D}}$, ONG, M.C. ${ }^{\mathrm{E}}$, \\ AND BHUBALAN, K. ${ }^{F^{*}}$
}

a,b,c,d,e,fFaculty of Science and Marine Environment, Universiti Malaysia Terengganu, 21030 Kuala Nerus, Terengganu, Malaysia; Institute Marine Biotechnology, Universiti Malaysia Terengganu, 21030 Kuala Nerus, Terengganu, Malaysia; ${ }^{f}$ Malaysian Institute of Pharmaceuticals and Nutraceuticals (IPharm), NIBM, Pulau Pinang, Malaysia

*Corresponding author: kesaven@umt.edu.my

\begin{abstract}
Mangrove located near urban area is exposed to various industrial discharge including heavy metals. Mangrove soil is capable of accumulating and storing these heavy metals. Heavy metals are toxic and non-biodegradable, so their accumulations affect water quality, while bioaccumulation and bio-assimilation of heavy metals in mangrove organisms negatively impact the food chain. Bacteria-derived biosurfactants are compounds capable of removing heavy metals from soil and sediment. Furthermore, environmentally friendly properties, such as biodegradability and low toxicity, exhibited by biosurfactants make them a suitable replacement for chemical surfactants for remediation efforts. This study was conducted to investigate the lead- $(\mathrm{Pb})$ and zinc- $(\mathrm{Zn})$ removing capability of rhamnolipid (RL), a type of biosurfactant produced by marine bacterium, Pseudomonas aeruginosa UMTKB-5. Rhamnolipid solutions of three different concentrations $(25 \mathrm{mg} / \mathrm{L}, 50 \mathrm{mg} / \mathrm{L}$ and $75 \mathrm{mg} / \mathrm{L}$ ) were added to mangrove soil and incubated for 7 days. The removal of $\mathrm{Pb}$ from soils was up to $18.3 \%$ using $25 \mathrm{mg} / \mathrm{L}$ RL solution, while $50 \mathrm{mg} / \mathrm{L}$ RL solution removed $48.3 \%$, and 75 $\mathrm{mg} / \mathrm{L}$ RL solution removed $75.9 \% \mathrm{~Pb}$ over time. Meanwhile, zinc removal of $25 \mathrm{mg} / \mathrm{L} \mathrm{RL}$ solution was up to $24.9 \%$, while $50 \mathrm{mg} / \mathrm{L}$ removed $16.5 \%$, and $75 \mathrm{mg} / \mathrm{L} \mathrm{RL}$ removed $30.5 \%$ of $\mathrm{Zn}$. The results showed that RL from $P$. aeruginosa UMTKB-5 could be a potential biomaterial to be used to remediate heavy metals in sediment.
\end{abstract}

Keywords: biosurfactant, rhamnolipid, heavy metal, remediation, Pseudomonas aeruginosa

\section{Introduction}

Environmental contamination by heavy metals is largely known to be caused by rapid industrialization, urbanization and most anthropogenic actions, such as burning fossil fuels, mining, smelting, using pesticides, as well as discharging wastes from automotive exhaust, agricultural and domestic activities (Wuana \& Okieimen, 2011). These released heavy metals eventually accumulate in soils. Soil and sediment are known to be sinks for the accumulation of heavy metals, especially mangrove sediment typically located near anthropogenic areas (Juwarkar et al., 2007).

Despite occurring at seemingly minuscule environmental amounts, the accumulation of heavy metals affects water quality, endangers wild and agricultural flora as well as fauna through bioaccumulation, thereby harming organisms at higher trophic levels of the food chain via biomagnification, especially humans (Juwarkar et al., 2007). By means of ingestion, inhalation and dermal contact, humans' exposure to heavy metals poses detrimental medical conditions, which include skin lesions, cancer, birth defects, organ damage, as well as retardation of physical and mental health (Singh \& Cameotra, 2004). In the current era of rapid urbanization and industrial development, environmental pollution has been a major concern increasingly receiving public awareness. Such awareness has given rise to the call for the restoration or remediation of metal-contaminated environments. Since heavy metals cannot be easily biodegraded, research has steered towards conversion of the redox state of harmful heavy metals into a precipitated or volatilized, less toxic form (Singh \& Cameotra., 2004). 
Biosurfactants, a type of natural biologically-synthesised surface-active compound, are known to form ionic bonds with toxic heavy metals, which generate non-ionic metal-biosurfactant complexes with stronger stability thus less toxicity (Rufino et al., 2012). Microorganisms produce biosurfactants as one of their metabolites because they constantly evolve their mechanisms for survival by adapting to or utilizing heavy metals for fundamental physiological functions, such as motility, biofilm formation, oil metabolization, cellular energy production and enzymatic reactions (Singh et al., 2007; Gadd, 2010). Common microbial biosurfactants include emulsan by Acinetobacter calcoaceticus (Shoham et al., 1983), sophorolipids by Candida bombicola (Kurtzman et al., 2010), and rhamnolipid (RL) by Pseudomonas aeruginosa (Azemi et al., 2016).

The biosurfactant known as RL, biosynthesised using $P$. aeruginosa, is an imperative biotechnological product with a wide range of applications. Due to its emulsifying, antiadhesive, antimicrobial and antifungal properties to name a few, RL possesses commercial prospects in biomedicine, cosmetics, food industry, agriculture, and heavy metal remediation (Mulligan et al., 2001). Biosurfactants are preferred over synthetic surfactants especially in environmental industries, as biosurfactants have been reported for their diversity, low toxicity, biodegradability, potential for large-scale commercial production, broader metal selectivity, broader tolerance to $\mathrm{pH}$, salinity and temperature, as well as producibility from by-product or industrial waste utilisation (Makkar et al., 2011; Sriram et al., 2011; Marchant \& Banat, 2012).

Moreover, studies on the production of biosurfactants using marine bacteria have not been extensively done in Malaysia. Also, studies on heavy metal removal by bacteria will certainly provide a novel finding in Malaysia. Furthermore, the current study will set a precedent for using marine bacteria to produce biosurfactant to remediate heavy metals in soil. Therefore, in the present study, the bioremediation ability of RL biosynthesised from isolated marine bacterium $P$. aeruginosa UMTKB-5 in reducing heavy metals from mangrove sediment was investigated.

\section{Materials and Methods}

\section{Strain Maintenance and Preparation of Inoculum}

P. aeruginosa UMTKB-5 (GenBank accession number KT194193.1), a marine sediment isolate, was used in this study (Azemi et al., 2016). Pre-culture was followed by activation phase before biosynthesis process to ensure adaptation of bacteria from solid to liquid medium for the preparation of inoculum. Two loopfuls of bacteria were transferred into $250-\mathrm{mL}$ conical flask containing $50 \mathrm{~mL}$ nutrient rich broth and placed in an incubator shaker, Ecotron $\mathrm{CH}-4103$ (INFORS HT, Switzerland) then incubated for $12 \mathrm{~h}\left(200 \mathrm{rpm}, 30^{\circ} \mathrm{C}\right)$. The steps were repeated to conduct second activation (Rahman et al., 2003; Christova et al., 2013).

\section{Biosynthesis of RL}

Mineral salt medium (MSM) used for biosynthesis of RL comprised of $2.80 \mathrm{~g} / \mathrm{L}$ potassium dihydrogen phosphate $\left(\mathrm{KH}_{2} \mathrm{PO}_{4}\right)$ (R\&M, Malaysia), $3.3 \mathrm{~g} / \mathrm{L}$ disodium hydrogen phosphate $\left(\mathrm{Na}_{2} \mathrm{HPO}_{4}\right)(\mathrm{R} \& \mathrm{M}$, Malaysia) and 0.25 $\mathrm{g} / \mathrm{L}$ of urea $\left(\mathrm{CO}\left(\mathrm{NH}_{2}\right)_{2}\right)$ (Merck, USA) (Azemi et al., 2016). MSM was also supplemented by $1 \mathrm{~mL} / \mathrm{L}$ trace elements solution, $1 \mathrm{~mL} / \mathrm{L}$ of $0.25 \mathrm{~g} / \mathrm{L}$ magnesium sulphate heptahydrate $\left(\mathrm{MgSO}_{4} \cdot 7 \mathrm{H}_{2} \mathrm{O}\right), 20 \mathrm{~g} / \mathrm{L}$ of glycerol and $7 \%(\mathrm{v} / \mathrm{v})$ bacterial cells of pre-culture medium (Christova et al., 2013, Azemi et al., 2016). Then, the medium was incubated using Ecotron $\mathrm{CH}-4103$ (INFORS HT, Switzerland) for $72 \mathrm{~h}(200 \mathrm{rpm}$, $30^{\circ} \mathrm{C}$ ) (Azemi et al., 2016). The cultivation was done in triplicates in a final medium volume of $200 \mathrm{~mL}$ in 1L Erlenmeyer flask. 


\section{Cell Harvesting and Separation of Supernatant}

After $72 \mathrm{~h}$ of biosynthesis, the medium was subjected to a centrifugation speed of $8000 \mathrm{rpm}$ for $5 \mathrm{~min}$ at $4^{\circ} \mathrm{C}$ for separation of cell pellet and supernatant (Yin et al., 2009). The cell pellets were subjected to oven drying at a temperature of $105^{\circ} \mathrm{C}$ until the cell dry weight (CDW) achieved was consistent. Meanwhile, supernatant was stored in $4^{\circ} \mathrm{C}$ chiller, 2D-DC-GE (JUSCOOL, Malaysia) until use for quantification of RL and subsequent extraction of RL.

\section{RL Quantification}

The RL content in supernatant was quantified using Orcinol assay technique (Ballot, 2009). In a microcentrifuge tube, $750 \mu \mathrm{L}$ diethyl ether (AR Grade) was utilized to extract $400 \mu \mathrm{L}$ of RL-containing supernatant. The microcentrifuge tube was vortexed for $3 \mathrm{~min}$ to obtain the upper ether fraction which was transferred into another microcentrifuge tube. The extraction process was repeated twice and the microcentrifuge tube containing upper fraction was left overnight to be dried. The following steps proceeded with the addition of $400 \mu \mathrm{L}$ phosphate buffer solution (PBS) (pH 8) and the mixing of $900 \mu \mathrm{L}$ Orcinol assay with $100 \mu \mathrm{L}$ PBS-added mixture, which was afterwards placed in a water bath for $30 \mathrm{~min}$ at $80^{\circ} \mathrm{C}$ (Azemi et al., 2016). Orcinol assay was prepared as described by Azemi et al. (2016). Before obtaining the absorbance reading at $421 \mathrm{~nm}$, the solution was left in a cupboard for 35 min (Ballot, 2009; Abdel-Mawgoud et al., 2011). The concentration was multiplied by 2.25 as correction factor to account for the relative proportion of congeners of RL and the lipid portion (Déziel et al., 2000).

\section{RL Extraction}

The RL extraction from supernatant was done according to a study by Yin et al. (2009). Supernatant was acidified to $\mathrm{pH} 2$ using $6 \mathrm{M}$ hydrogen chloride $(\mathrm{HCl})$. Later, in a separating funnel, ethyl acetate and supernatant were added at 1:1 ratio, and the separating funnel was shaken vigorously for about $3 \mathrm{~min}$. The funnel was left aside until phase separation occurred where the upper fraction containing RL was taken. This step was repeated twice and, to remove excess water, the upper fraction was transferred into conical flask where it was added with anhydrous sodium sulphate and left aside for about $30 \mathrm{~min}$. After that, Buchi 1234 (Buchi, Japan), a rotary evaporator, was used to extract the crude RL with a $40^{\circ} \mathrm{C}$ water bath. The $0.05 \mathrm{M}$ sodium bicarbonate was used to dissolve crude RL, after which $6 \mathrm{M}$ of $\mathrm{HCl}$ was used to tune the $\mathrm{pH}$ to $\mathrm{pH}$ 2. Then, a chiller of $4^{\circ} \mathrm{C}$ was used as 24 -h storage for the solution. Subsequently, the solution was subjected to a 15-min centrifugation at 12500 rpm. Then, using MDF-U537 (Sanyo, Japan) Biomedical Freezer, the RL precipitate was stored at $-80^{\circ} \mathrm{C}$ overnight before Freezone 4.5 Freezer Dry System (Labconco, USA) was used to freeze-dry the precipitated RL for $24 \mathrm{~h}$.

\section{Sample Collection and Heavy Metal Analysis}

Sampling was done in mangrove area in Universiti Malaysia Terengganu (UMT) due to proximity with urban development activities. Mangrove soil samples were collected in replicates using Ponar grab to obtain surface soil at approximately $10 \mathrm{~cm}$ depth. To ensure undisturbed grain-size distribution, precautionary steps were taken to reduce soil disturbance during sampling. Only samples that were collected with firmly-closed grab sampler and only inner soil was selected as acceptable for use. Sterile plastic containers and an approximate temperature of $4^{\circ} \mathrm{C}$ were provided for post-collection storage prior to further analysis (Azrina et al., 2006). Then, digestion of soil samples was carried out to subsequently analyse the samples for total lead $(\mathrm{Pb})$ and Zinc (Zn) (Defew et al., 2005).

Sample that was finely powdered and weighed to $50 \mathrm{mg}$, as well as $1.5 \mathrm{~mL}$ mixed acid solution of concentrated hydrofluoric acid, nitric acid and $\mathrm{HCl}$, were placed into a sealed Teflon vessel to be heated using the digestion method. The ratio of the acids was 1:3:3. The Teflon vessel was heated for $7 \mathrm{~h}$ at $100^{\circ} \mathrm{C}$. After that, 
the vessel was cooled until room temperature was achieved. A $10-\mathrm{mL}$ polypropylene test tube was used for the content to be transferred into. Next, deionised water was used to dilute the content to $10 \mathrm{~mL}$. At the last stage, a clear solution with absence of residue was acquired. Precise and quick determination of $\mathrm{Pb}$ and $\mathrm{Zn}$ in the digested soil was carried out using atomic absorption spectroscopy (AAS) (Yunus et al., 2011). A precision threshold of less than $3 \%$ that was evaluated by the replicate analyses was considered as acceptable (Yunus et al., 2011). Duplicate Canadian Certified Reference Material Project MESS-3 was analysed to examine the accuracy of the result that was within the certified value of $\pm 3 \%$.

\section{Heavy Metal Removal}

Soil heavy metal removal was done based on methods prescribed by da Rocha Junior et al., (2018) with some modifications. A total of $5 \mathrm{~g}$ of soil samples were transferred into wide mouth conical flasks and RL was added in different concentrations of $75 \mathrm{mg} / \mathrm{L}, 50 \mathrm{mg} / \mathrm{L}$, and 25 $\mathrm{mg} / \mathrm{L}$. The experiment was done in triplicates for each concentration. Later, $0.05 \mathrm{~g}$ of soil was collected at selected interval for heavy metal analysis. The experiment was conducted for a total of 7 days.

\section{Results}

Table 1 shows RL production by $P$. aeruginosa UMTKB-5 when supplemented with glycerol as substrate. The cells were able to yield up to 1.8 $\mathrm{g} / \mathrm{L}$ of RL concentration which translated to an estimated $2.5 \mathrm{~g} / \mathrm{L}$ RL per gram of cells.

Table 1: Concentration and yield of RL biosynthesised by Pseudomonas aeruginosa UMTKB-5 utilising glycerol as a carbon source.

\begin{tabular}{|c|c|c|c|}
\hline $\begin{array}{c}\text { RL concentration }{ }^{\text {a }} \\
(\mathrm{g} / \mathrm{L})\end{array}$ & $\begin{array}{c}\text { Cell Dry Weight (CDW), } \\
(\mathrm{g} / \mathrm{L})\end{array}$ & $\begin{array}{c}\text { Yield of RL } \\
\mathbf{Y}_{\mathrm{RL} / \mathrm{CDW}}{ }^{\mathrm{b}}(\mathrm{g} / \mathrm{g})\end{array}$ & $\begin{array}{l}\text { Yield of RL } \\
Y_{R L / s}{ }^{c}(g / g)\end{array}$ \\
\hline $1.80 \pm 0.03$ & $0.42 \pm 0.01$ & $2.5 \pm 0.2$ & $0.05 \pm 0.01$ \\
\hline
\end{tabular}

${ }^{a} \mathrm{RL}$ concentration was determined using orcinol assay, ${ }^{\mathrm{b}} \mathrm{Y}_{\mathrm{RL} / \mathrm{CDW}}$, yield of per gram of RL per gram cell CDW,

${ }^{c} \mathrm{Y}_{\mathrm{RL} / \mathrm{S}}$, Yield of per gram of RL per gram of substrate, data show the mean \pm standard deviation of triplicates.

Figure 1 and 2 show $\mathrm{Pb}$ and $\mathrm{Zn}$ removal by three different concentrations of RL solutions respectively over a seven-day period. In general, both $\mathrm{Pb}$ and $\mathrm{Zn}$ were removed by all tested concentrations of RL. It was observed that 75 $\mathrm{mg} / \mathrm{L}$ of RL solution removed higher amount of $\mathrm{Pb}$ and $\mathrm{Zn}$ compared to $50 \mathrm{mg} / \mathrm{L}$ and $25 \mathrm{mg} / \mathrm{L}$ of RL solution. However, the finding of this study revealed significant dissimilarity in the metal removal of $\mathrm{Pb}$ and $\mathrm{Zn}$, where $\mathrm{RL}$ solutions were able to remove $\mathrm{Pb}$ better than $\mathrm{Zn}$ at all tested $\mathrm{RL}$ concentrations.

Results showed that $75 \mathrm{mg} / \mathrm{L}$ of RL solution was able to remove $82.45 \%$ of $\mathrm{Pb}$ compared to $30.50 \%$ of $\mathrm{Zn}$ which showed a $51.95 \%$ removal difference. Similar result was observed at 50 $\mathrm{mg} / \mathrm{L}$ of $\mathrm{RL}$ solution where $63.07 \%$ of $\mathrm{Pb}$ was removed compared to $24.90 \%$ of $\mathrm{Zn}$. Based on Figure 2, $\mathrm{Zn}$ removal was only recorded until day 4 for all test conditions and no further removal was observed on day 7 . 
Figure 1: Removal of $\mathrm{Pb}$ in mangrove soils from 1 to 7 days by different concentration of isolated Rhamnolipid (RL) at $75 \mathrm{mg} / \mathrm{L}, 50 \mathrm{mg} / \mathrm{L}$ and $25 \mathrm{mg} / \mathrm{L}$ RL solutions.

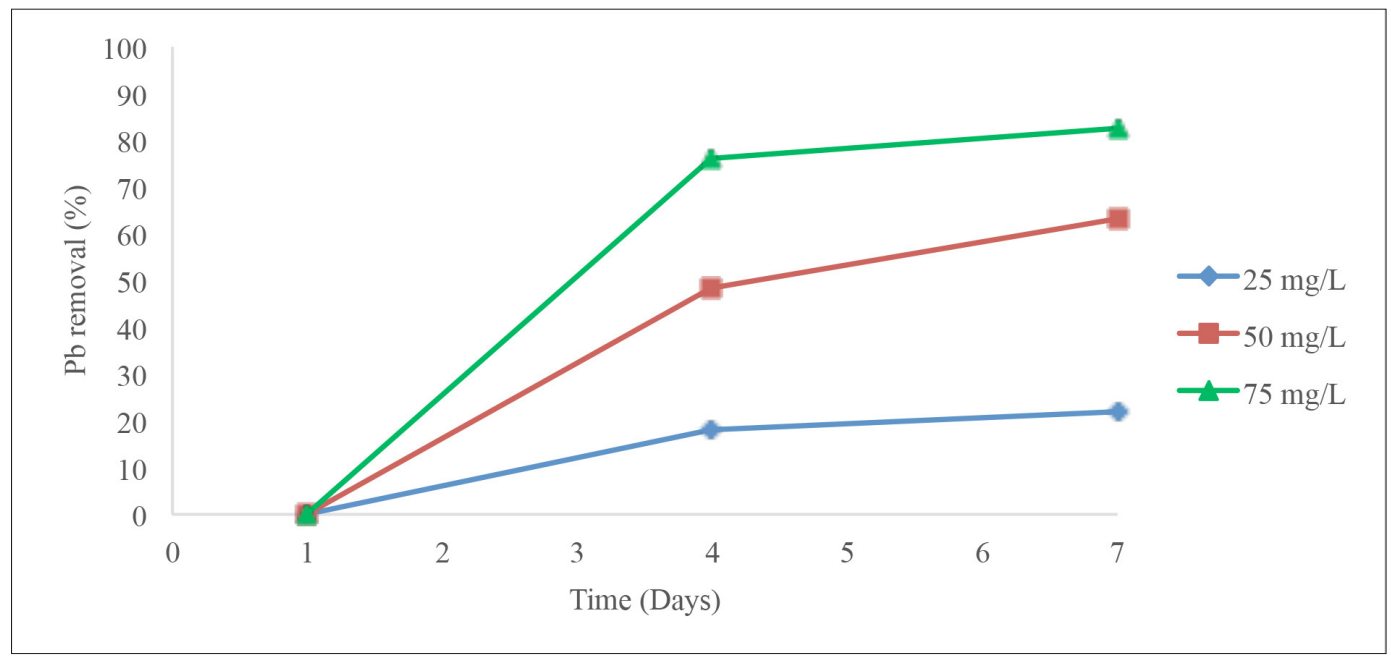

Figure 2: Removal of $\mathrm{Zn}$ in mangrove soils from 1 to 7 days by different concentration of isolated Rhamnolipid (RL) at $75 \mathrm{mg} / \mathrm{L}, 50 \mathrm{mg} / \mathrm{L}$ and $25 \mathrm{mg} / \mathrm{L}$ RL solutions.

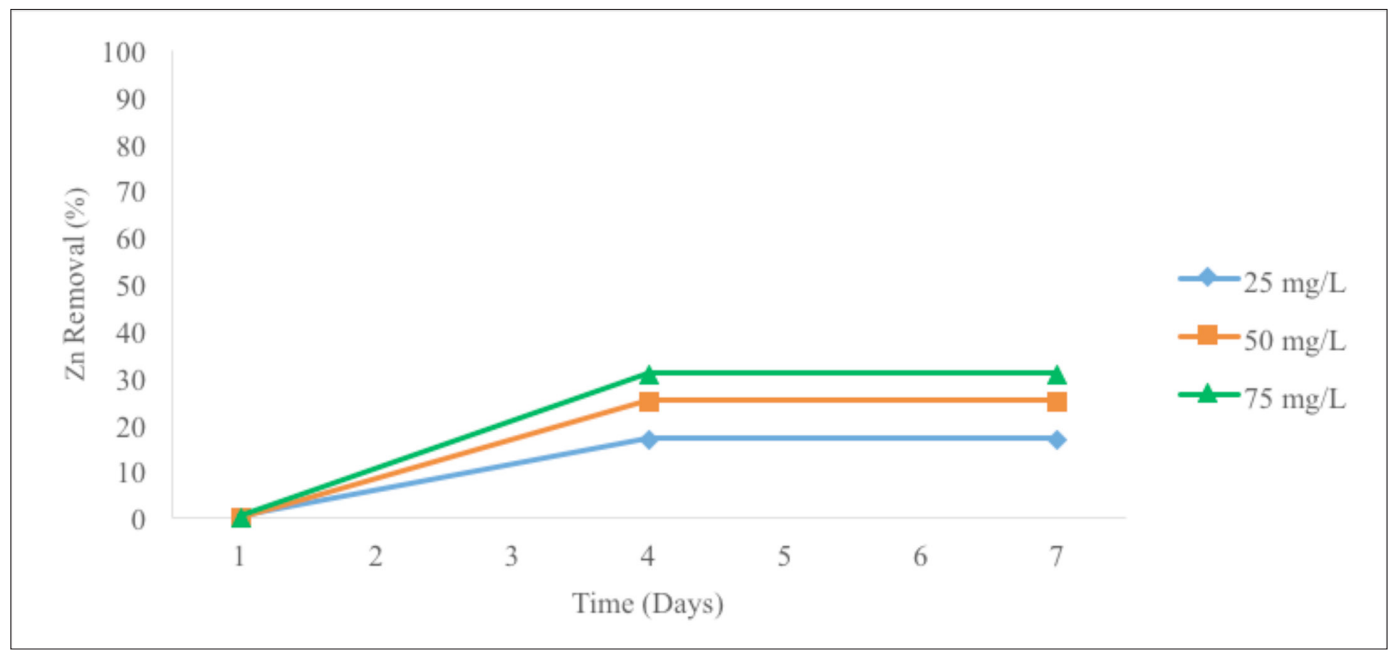

\section{Discussion}

RL concentration produced in this study was approximately $17 \%$ higher than in a previous study reported by Rashid et al., (2015) where the concentration obtained was $1.49 \pm 0.9 \mathrm{~g} / \mathrm{L}$. Both studies utilized the same carbon source and bacterial strain, which was glycerol (20 $\mathrm{g} / \mathrm{L})$ and $P$. aeruginosa UMTKB-5 respectively. However, different nitrogen sources were used, whereby $\mathrm{CO}\left(\mathrm{NH}_{2}\right)_{2}$ was used in this study and ammonium chloride $\left(\mathrm{NH}_{4} \mathrm{Cl}\right)$ was used in the study by Rashid et al. (2015). The different nitrogen source may have caused the difference in the RL concentration. Similar result was reported in a previous study by Wei et al (2008), whereby high RL concentration was produced by $P$. aeruginosa J16 when supplemented with $\mathrm{CO}\left(\mathrm{NH}_{2}\right)_{2}$ as nitrogen source compared to $\mathrm{NH}_{4} \mathrm{Cl}$. 
It has been reported that RL has different affinities for bonding with different metals (Mulligan, 2004; Dahrazma \& Mulligan, 2007), in the following descending order: $\mathrm{Al}^{3+}>\mathrm{Cu}^{2+}$ $>\mathrm{Pb}^{2+}>\mathrm{Cd}^{2+}>\mathrm{Zn}^{2+}>\mathrm{Fe}^{3+}>\mathrm{Hg}^{2+}>\mathrm{Ca}^{2+}$ $>\mathrm{Co}^{2+}>\mathrm{Ni}^{2+}>\mathrm{Mn}^{2+}>\mathrm{Mg}^{2+}>\mathrm{K}^{+}$(OchoaLoza et al., 2001). This shows that RL in soil can remove $\mathrm{Pb}$ and $\mathrm{Zn}$ from the sediment. A study was done by Wang and Mulligan (2009) on heavy metal removal with soil flushing, which included $\mathrm{As}, \mathrm{Cu}, \mathrm{Pb}, \mathrm{Zn}$ and $\mathrm{Fe}$. The RL-metal complexes had stability constants reported in the following order: $\mathrm{Cu}^{2+}>\mathrm{Pb}^{2+}>\mathrm{Zn}^{2+}>\mathrm{Fe}^{3+}$. The reported results corroborate the findings of the current study where $\mathrm{Pb}$ was removed at higher percentage compared to Zn. Natural-occurring organic ligands, such as humic or fluvic acids, and RL can form complexes with metals (Ochoa-Loza et al., 2001). However, metals had a higher stability constant with RL compared to the organic ligands mentioned (OchoaLoza et al., 2001). Thus, RL performs better in removing heavy metals despite other potential and naturally occurring elements that can bind with metals in the soil. Furthermore, a previous study by Neilson et al. (2003) primarily on removal of $\mathrm{Pb}$ by $\mathrm{RL}$ showed that $15 \% \mathrm{~Pb}$ was removed by $10 \mathrm{mM}$ solution of RL.

However, heavy metals cannot be degraded by RL and form strong bonds with soil, causing difficulty in removal by RL (Singh \& Cameotra, 2004). The efficiency of heavy metal removal by $\mathrm{RL}$ is dependent on soil composition and $\mathrm{pH}$, particle size, capacity of cation exchange, type of contamination and the time of occurrence as well as geological layout (Mulligan et al., 2001). RL biosynthesised by $P$. aeruginosa strains has been reported to form bonds with complex cationic metal species including $\mathrm{Zn}, \mathrm{Cd}$, and $\mathrm{Pb}$. Furthermore, the RL from this strain is less likely to form complexes with normal soil metal cations of lower affinities, such as $\mathrm{Mg}$ and $\mathrm{Ca}$, than toxic metals, such as $\mathrm{Pb}$ and $\mathrm{Cd}$ (Singh \& Cameotra., 2004).

Mulligan et al. (2001) hypothesised that the removal of metals using biosurfactants is related to surfactant micelles through surfactant adsorption to surface of the soil, complex- forming with metal, and detachment of metal from soil hence into the solution. It is possible that the removal of $\mathrm{Zn}$ in mangrove soil remained unchanged from day 4 to 7 due to insufficient binding sites or low concentration of $\mathrm{RL}$ as approximately 2 moles of $\mathrm{RL}$ is required to bind to per mole of metal (Ochoa-Loza et al.2001). Thus, affinity and number of binding sites proportionally related to the concentration of RL (Ochoa-Loza et al., 2001; Sandrin et al.,2000).

To completely remove heavy metals, Singh and Cameotra (2004) suggested that the soil be treated with biosurfactant using appropriate mixing method. The positive-charged metals and negative-charged surfactant form strong bonds sufficient for surfactant metal complexes to be removed by water-flushing, thereby leaving metal-free soil (Singh \& Cameotra, 2004). The biosurfactant could be subjected to multiple recycling as the biosurfactant was not degraded by the recovery method (Wang \& Mulligan, 2009). Consequently, the application potential of the RL biosynthesised by $P$. aeruginosa UMTKB-5 for heavy metal remediation process is highlighted by the findings of this study.

\section{Conclusions}

This study demonstrates that RL produced by the isolated marine bacterium $P$. aeruginosa UMTKB-5 has potential heavy metals removing ability when tested with mangrove soils. Due to the low toxicity of the biosurfactant, it is very promising for use in metal removal. It is recommended that further studies be conducted with the soil-washing technique where the biosurfactant-metal complex is flushed out and more $\mathrm{RL}$ is added within the time series.

\section{Acknowledgements}

This study was supported by the Exploratory Research Grant Scheme (ERGS) [ERGS/1/2013/ STG07/UMT/03/02] awarded by Ministry of Higher Education, Malaysia and internal funds from the School of Marine and Environmental Sciences, Universiti Malaysia Terengganu. 


\section{References}

Abdel-Mawgoud, A. M., Hausmann, R., Lépine, F., Müller, M. M., \& Déziel, E. (2011). Rhamnolipids: Detection, analysis, biosynthesis, genetic regulation, and bioengineering of production. In Soberón Chávez, G. (Ed.), Biosurfactants (pp. 1355). Berlin, Heidelberg: Springer. http://doi. org/10.1007/978-3-642-14490-5_2

Azemi, M. A. F. M., Rashid, N. F. M., Saidin, J., Effendy, A. W. M., \& Bhubalan, K. (2016). Application of Sweetwater as Potential Carbon Source for RL Production by Marine Pseudomonas aeruginosa UMTKB-5. International Journal of Bioscience, Biochemistry and Bioinformatics, 6(2), 50.

Azrina, M. Z., Yap, C. K., Ismail, A. R., Ismail, A., \& Tan, S. G. (2006). Anthropogenic impacts on the distribution and biodiversity of benthic macroinvertebrates and water quality of the Langat River, Peninsular Malaysia. Ecotoxicology and environmental safety, 64(3), 337-347.

Ballot, F. (2009). Bacterial production of antimicrobial biosurfactants (Doctoral dissertation, Stellenbosch: University of Stellenbosch).

Christova, N., Tuleva, B., Kril, A., Georgieva, M., Konstantinov, S., Terziyski, I., Nikolova, B., \& Stoineva, I. (2013). Chemical structure and in vitro antitumor activity of rhamnolipids from Pseudomonas aeruginosa BN10. Applied Biochemistry and Biotechnology, 170(3), 676-689.

da Rocha Junior, R. B., Meira, H. M., Almeida, D. G., Rufino, R. D., Luna, J. M., Santos, V. A., \& Sarubbo, L. A. (2018). Application of a low-cost biosurfactant in heavy metal remediation processes. Biodegradation, 1-19.

Dahrazma, B., \& Mulligan, C. N. (2007). Investigation of the removal of heavy metals from sediments using rhamnolipid in a continuous flow configuration. Chemosphere, 69(5), 705711.
Defew, L. H., Mair, J. M., \& Guzman, H. M. (2005). An assessment of metal contamination in mangrove sediments and leaves from Punta Mala Bay, Pacific Panama. Marine Pollution Bulletin, 50(5), 547-552.

Déziel, E., Lépine, F., Milot, S., \& Villemur, R. (2000). Mass spectrometry monitoring of rhamnolipids from a growing culture of Pseudomonas aeruginosa strain 57RP. Biochimica et Biophysica Acta (BBA)-Molecular and Cell Biology of Lipids, 1485(2), 145-152.

Gadd, G. M. (2010). Metals, minerals and microbes: Geomicrobiology and bioremediation. Microbiology, 156, 609643.

Juwarkar, A. A., Nair, A., Dubey, K. V., Singh, S. K., \& Devotta, S. (2007). Biosurfactant technology for remediation of cadmium and lead contaminated soils. Chemosphere, 68(10), 1996-2002.

Kurtzman, C. P., Price, N. P., Ray, K. J., \& Kuo, T. M. (2010). Production of sophorolipid biosurfactants by multiple strains of the Starmerella (Candida) bombicola yeast clade. FEMS Microbiology Letters, 311(2), 140-146. http://doi. org/10.1111/j.1574-6968.2010. 02082.x

Lee, K. M., Hwang, S. H., Ha, S. D., Jang, J. H., Lim, D. J., \& Kong, J.Y (2004). Rhamnolipid production in batch and fedbatch fermentation using Pseudomonas aeruginosa BYK-2 KCTC 18012P. Biotechnology and Bioprocess Engineering, 9(4), 267-273.

Makkar, R. S., Cameotra, S. S., \& Banat, I. M. (2011). Advances in utilization of renewable substrates for biosurfactant production. Applied Microbiology and Biotechnology Express, 1, 5. http://doi.org/10.1186/21910855-1-5

Marchant, R., \& Banat, I. M. (2012). Microbial biosurfactants: Challenges and opportunities for future exploitation. Trends in biotechnology, 30(11), 558-565. 
Mulligan, C. N., Yong, R. N., \& Gibbs, B. F. (2001). Heavy metal removal from sediments by biosurfactants. Journal of Hazardous Materials, 85(1), 111-125.

Mulligan, C. N., \& Gibbs, B. F. (2004). Types, production and applications of biosurfactants. Proceedings-Indian National Science Academy Part B, 70(1), 31-56.

Neilson, J. W., Artiola, J. F., \& Maier, R. M. (2003). Characterization of lead removal from contaminated soils by nontoxic soilwashing agents. Journal of Environmental Quality, 32(3), 899-908.

Ochoa-Loza, F. J., Artiola, J. F., \& Maier, R. M. (2001). Stability constants for the complexation of various metals with a rhamnolipid biosurfactant. Journal of Environmental Quality, 30(2), 479-485.

Rahman, K. S. M., Rahman, T. J., Kourkoutas, Y., Petsas, I., Marchant, R., \& Banat, I. M. (2003). Enhanced bioremediation of $\mathrm{n}$-alkane in petroleum sludge using bacterial consortium amended with rhamnolipid and micronutrients. Bioresource Technology, 90(2), 159-168.

Rashid, N., Azemi, M., Amirul, A., Wahid, M., \& Bhubalan, K. (2015). Simultaneous production of biopolymer and biosurfactant by genetically modified Pseudomonas aeruginosa UMTKB-5. International Proceedings of Chemical, Biological And Environmental Engineering, 90(3), 16-21.

Rufino, R. D., Luna, J. M., Campos-Takaki, G. M., Ferreira, S. R. M., \& Sarubbo, L. A. (2012). Application of the biosurfactant produced by Candida lipolytica in the remediation of heavy metals. Chemical Engineering Transactions, 27, 61-66.

Sandrin, T. R., Chech, A. M., \& Maier, R. M. (2000). A rhamnolipid biosurfactant reduces cadmium toxicity during naphthalene biodegradation. Applied and Environmental Microbiology, 66(10), 4585-4588.
Shoham, Y., Rosenberg, M., \& Rosenberg, E. (1983). Bacterial degradation of emulsan. Applied and Environmental Microbiology, 46(3), 573-579.

Singh, P., \& Cameotra, S. S. (2004). Enhancement of metal bioremediation by use of microbial surfactants. Biochemical and biophysical research communications, 319(2), 291-297.

Singh, A., Van Hamme, J. D., \& Ward, O. P. (2007). Surfactants in microbiology and biotechnology: Part 2. Application aspects. Biotechnology Advances, 25, 99-121.

Sriram, M. I., Gayathiri, S., Gnanaselvi, U., Jenifer, P. S., Mohan Raj, S., \& Gurunathan, S. (2011). Novel lipopeptide biosurfactant produced by hydrocarbon degrading and heavy metal tolerant bacterium Escherichia fergusonii KLU01 as a potential tool for bioremediation. Bioresource Technology, 102, 9291-9295.

Wang, S., \& Mulligan, C. N. (2009). Rhamnolipid biosurfactant-enhanced soil flushing for the removal of arsenic and heavy metals from mine tailings. Process Biochemistry, 44(3), 296-301.

Wei, Y. H., Cheng, C. L., Chien, C. C., \& Wan, H. M. (2008). Enhanced di-rhamnolipid production with an indigenous isolate Pseudomonas aeruginosa J16. Process Biochemistry, 43(7), 769-774.

Wuana, R. A., \& Okieimen, F. E. (2011). Heavy metals in contaminated soils: A review of sources, chemistry, risks and best available strategies for remediation. ISRN Ecology, 2011, 402647.

Yin, H., Qiang, J., Jia, Y., Ye, J., Peng, H., Qin, H., Zhang, N., \& He, B. (2009). Characteristics of biosurfactant produced by Pseudomonas aeruginosa S6 isolated from oil-containing wastewater. Process Biochemistry, 44(3), 302-308.

Yunus, K., Mohd Yusuf, N., Shazili, M., Azhar, N., Ong, M. C., Saad, S., \& Bidai, J. (2011). Heavy metal concentration in the surface sediment of Tanjung Lumpur mangrove forest, Kuantan, Pahang, Malaysia. Sains Malaysiana, 40(2), 89-92. 